\title{
ДЕЯКІ ОСОБЛИВОСТІ ЯКОСТІ ЖИТТЯ ПРИ ПЕРВИННОМУ ЕПІЗОДІ БІПОЛЯРНОГО АФЕКТИВНОГО РОЗЛАДУ
}

\author{
Тернопільський національний медичний університет імені І. Я. Горбачевського МОЗ України, \\ м. Тернопіль, Україна
}

\begin{abstract}
Мета: вивчити особливості якості життя у хворих із первинним епізодом біполярного афективного розладу (БАР) з урахуванням статі та клінічного варіанта дебюту захворювання.

Матеріали і методи. Обстежено 153 хворих (65 чоловіків та 88 жінок) із первинним епізодом біполярного афективного розладу протягом 2011-2016рр. з використанням шкали якості життя Mezzich в адаптації Н. О. Марути.

Результати. Встановлено низькі показники якості життя при депресивному варіанті первинного епізоду БАР за всіма сорерами: суб'єктивного благополуччя/задоволеності - $(7,04 \pm 2,52)$ бала у всіх хворих, $(7,86 \pm 2,80)$ бала у чоловіків і $(6,56 \pm 2,21)$ бала у жінок $(p<0,05)$, виконання соціальних ролей - $(13,68 \pm 4,89)$ бала, $(15,18 \pm 4,29)$ бала і $(12,80 \pm 5,03)$ бала $(p<0,05)$, зовнішніх життєвих умов - $(16,11 \pm 5,73)$ бала, $(17,34 \pm 5,47)$ бала і $(15,39 \pm 5,78)$ бала (р>0,05), а також сумарного показника якості життя - $(36,83 \pm 12,52)$ бала, $(40,39 \pm 12,03)$ бала і $(34,75 \pm 12,41)$ бала $($ р<0,05). У хворих із маніакальним варіантом показники за всіма ссрерами є високими: відповідно $(26,91 \pm 3,64)$ бала, $(28,07 \pm 2,96)$ бала і $(24,75 \pm 3,99)$ бала $(p<0,05) ;(36,78 \pm 3,91)$ бала, $(38,20 \pm 3,10)$ бала і $(34,13 \pm 4,05)$ бала $(p<0,05) ;(26,70 \pm 3,10)$ бала, $(27,80 \pm 2,91)$ бала і $(24,63 \pm 2,39)$ бала $(p<0,05)$ та $(90,39 \pm 10,35)$ бала, $(94,07 \pm 8,79)$ бала і $(83,50 \pm 9,96)$ бала (p<0,05), а при змішаному варіанті - помірними: відповідно $(6,91 \pm 4,30)$ бала, $(8,50 \pm 4,76)$ бала i $(5,00 \pm 3,08)$ бала $(p>0,05) ;(13,09 \pm 6,55)$ бала, $(15,67 \pm 7,37)$ бала i $(10,00 \pm 4,18)$ бала $(p>0,05) ;(13,91 \pm 4,46)$ бала, $(16,00 \pm 3,85)$ бала і $(11,40 \pm 4,10)$ бала $(p>0,05)$ та $(33,91 \pm 14,96)$ бала, $(40,17 \pm 15,78)$ бала i $(26,40 \pm 10,92)$ бала $(p>0,05)$.

Висновки. При депресивному варіанті первинного епізоду БАР виявлено низьку, а при маніакальному - високу самооцінку якості життя за всіма сорерами, що зумовлено впливом актуального стану афективної сфрери. При змішаному варіанті первинного епізоду виявлено помірні показники якості життя, що пов'язано з поліморфністю клінічних проявів та нестійкістю психоемоційного стану. У жінок показники якості життя за основними сферами нижчі, ніж у чоловіків, що пов'язано з більшою вираженістю депресивних проявів.
\end{abstract}

КЛЮЧОВІ СЛОВА: біполярний афективний розлад; первинний епізод; якість життя.

Проблема біполярного афрективного розладу (БАР) є однією 3 найактуальніших проблем у сучасній психіатрії $[2,3,6]$. БАР супроводжується вираженими порушеннями психосоціального фрункціонування хворих, включаючи значне погіршення якості життя (ЯЖ) $[7,9,10]$. Погіршення ЯЖ при БАР має важливе значення для загальної оцінки стану пацієнта; воно може бути пов'язано 3 несвоєчасними або недостатньо ефективними лікувальними заходами, неправильним способом життя і з особливостями патодинаміки біполярного розладу [5, 8]. Сучасна психіатрія розглядає як кінцеву мету лікування БАР у клінічних та дослідницьких умовах не тільки досягнення клінічної ремісії, а й забезпечення фрнкціонального й особистісного одужання, що полягає у відновленні благополуччя пацієнта та його яЖ, а для вирішення цього завдання проблему БАР необхідно розглядати цілісно та інтегративно [4]. Однак вивчення особливостей ЯЖ при первинному епізоді (ПЕ) БАР пов'язано зі значними технічними і методологічними труднощами, тож дані щодо особливостей ЯЖ у хворих із ПЕ БАР практично відсутні, що утруднює розробку сучасних методів лікування, реабілітації та профілактики БАР.

Мета дослідження: вивчити особливості якості життя у хворих із первинним епізодом БАР 3 урахуванням статі та клінічного варіанта дебюту захворювання.

Матеріали і методи. 3 дотриманням принципів біомедичної етики на основі інформованої згоди було обстежено 153 хворих (65 чоловіків та 88 жінок) 3 первинним епізодом біполярного афективного розладу, які перебували на лікуванні у Тернопільській обласній комунальній клінічній психоневрологічній лікарні у період 2011-2016 рр. Середній вік обстежених пацієнтів на момент виникнення симптоматики склав $(21,3 \pm 6,5)$ року (медіана - 19,0 років; інтерквартильний діапазон - 17,0-22,0 роки), чоловіків $(20,5 \pm 5,8)$ року (18,0 років; $17,0-21,0$ рік), жінок $(21,9 \pm 6,9)$ року $(18,5$ року; $18,5-22,5$ року), вік на момент звернення за медичною допомогою і обстеження - відповідно, $(21,4 \pm 6,4)$ року $(19,0$ років; $18,0-22,0$ роки), $(20,7 \pm 5,7)$ року $(18,0$ років; $17,0-21,0$ рік) та $(22,0 \pm 6,9)$ року $(19,0$ років; $18,5-$ 22,5 року). 
Серед обстежених чоловіків і жінок було виділено по три групи залежно від клінічного варіанта перебігу ПЕ БАР: з переважанням депресивної симптоматики (депресивний варіант), кількістю 119 осіб (44 чоловіки і 75 жінок); із переважанням маніакальної або гіпоманіакальної симптоматики (маніакальний варіант), кількістю 23 особи (15 чоловіків і 8 жінок), та з одночасною наявністю депресивної та маніакальної симптоматики або зі швидкою зміною фраз (змішаний варіант), кількістю 11 осіб (6 чоловіків і 5 жінок).

Обстеження проводили з використанням шкали якості життя Mezzich в адаптації Н. О. Марути [1].

Статистичну обробку даних здійснювали за допомогою непараметричного тесту Манна - Уїтні та точного критерію Фішера.

Результати дослідження та їх обговорення. Для хворих із депресивним варіантом ПЕ БАР характерні низькі показники за всіма сорерами ЯЖ, причому жінки виявили більш низькі показники ЯЖ порівняно 3 чоловіками. Так, середнє значення показника за сферою фрізичного благополуччя склало $(3,18 \pm 1,57)$ бала у

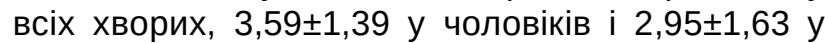
жінок, розбіжності між групами чоловіків та жінок статистично значущі $(p<0,05)$; за сорерою психологічного (емоційного) благополуччя -

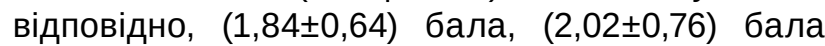
і $(1,73 \pm 0,53)$ бала ( $p<0,05)$; самообслуговування і незалежності дій - $(3,91 \pm 1,33)$ бала, $(4,25 \pm 1,10)$ бала і $(3,71 \pm 1,42)$ бала $(p<0,05)$; працездатності - $(2,80 \pm 1,24)$ бала, $(3,11 \pm 1,10)$ бала і $(2,61 \pm 1,28)$ бала $(p<0,05)$; міжособистісної взаємодії - $(4,09 \pm 1,66)$ бала, $(4,57 \pm 1,19)$ бала i $(3,81 \pm 1,84)$ бала $(p<0,05) ;$ соціально-емоційної підтримки - $(5,00 \pm 2,44)$ бала, $(5,61 \pm 2,09)$ бала i $(4,64 \pm 2,56)$ бала $(p<0,05)$; громадської та службової підтримки - $(6,34 \pm 1,92)$ бала, $(6,57 \pm 2,03)$ бала i $(6,21 \pm 1,86)$ бала ( $>0,05) ;$ особистісної реалізації - $(2,88 \pm 1,40)$ бала, $(3,25 \pm 1,42)$ бала і $(2,67 \pm 1,35)$ бала $(p<0,05)$; духовної реалізації - $(4,76 \pm 1,80)$ бала, $(5,16 \pm 1,68)$ бала i $(4,53 \pm 1,84)$ бала $(p<0,05)$; загального сприйняття життя - $(2,02 \pm 0,81)$ бала, $(2,25 \pm 0,97)$ бала i $(1,88 \pm 0,68)$ бала $(p<0,05)$. Цим хворим були притаманні також низькі показники за інтегральними сорерами: суб'єктивного благополуччя/задоволеності - $(7,04 \pm 2,52)$ бала, $(7,86 \pm 2,80)$ бала i $(6,56 \pm 2,21)$ бала $(p<0,05)$; виконання соціальних ролей - $(13,68 \pm 4,89)$ бала, $(15,18 \pm 4,29)$ бала і $(12,80 \pm 5,03)$ бала $(p<0,05) ;$ зовнішніх життєвих умов - $(16,11 \pm 5,73)$ бала, $(17,34 \pm 5,47)$ бала i $(15,39 \pm 5,78)$ бала $(p>0,05)$, а також низький сумарний показник ЯЖ - $(36,83 \pm 12,52)$ бала, $(40,39 \pm 12,03)$ бала і $(34,75 \pm 12,41)$ бала $(p<0,05)$.

У структурі самооцінки ЯЖ у хворих із депресивним варіантом ПЕ БАР домінує сорера зовнішніх життєвих умов: для цих хворих притаманні низькі показники за сферами суб'єктивного благополуччя/задоволеності та виконання соціальних ролей, які при депресії пригнічуються найбільше (рис. 1). У цілому 43,8 \% в структурі самооцінки ЯЖ займає сфера зовнішніх життєвих умов (42,9 \% у чоловіків, 44,3 \% в жінок), 37,1 \% сорера виконання соціальних ролей (відповідно 37,6 \% і 36,8 \%) і лише 19,1 \% (19,5 \% і 18,9 \%) сорера суб'єктивного благополуччя/задоволеності. Співвідношення самооцінки сорер життя у жінок та чоловіків значуще не відрізняється $(p>0,05)$.

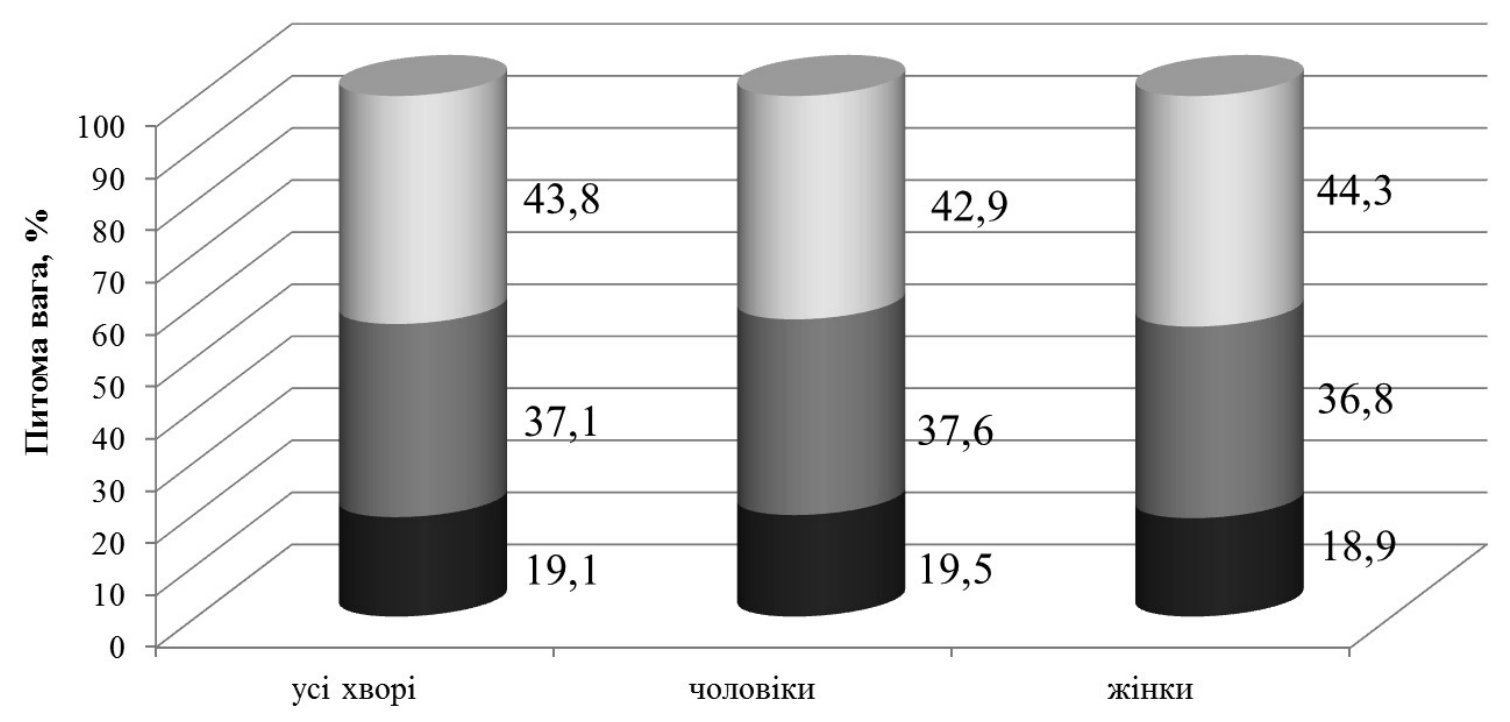

ॠ Зовнішні життєві умови в Виконання соціальних ролей $\quad$ Суб'єктивне благополуччя/задоволеність

Puc. 1. Структура самооцінки якості життя у різних сферах за шкалою Mezzich в адаптації н. О. Марути у хворих із депресивним варіантом ПЕ БАР. 
Для маніакального варіанта характерні високі оцінки за всіма ключовими сорерами з більш високими показниками у чоловіків. Так, середнє значення показника ЯЖ склало: за сферою фрізичного благополуччя - $(8,83 \pm 1,37)$ бала, $(9,20 \pm 1,26)$ бала і $(8,13 \pm 1,36)$ бала $(p<0,05)$; психологічного (емоційного) благополуччя $(9,09 \pm 1,20)$ бала, $(9,53 \pm 0,74)$ бала і $(8,25 \pm 1,49)$ бала $(p<0,05)$; самообслуговування і незалежності дій - $(9,35 \pm 0,83)$ бала, $(9,60 \pm 0,74)$ бала і $(8,88 \pm 0,83)$ бала $(p<0,05)$; працездатності - $(9,00 \pm 1,13)$ бала, $(9,40 \pm 0,99)$ бала і $(8,25 \pm 1,04)$ бала $(p<0,05)$; міжособистісної взаємодії - $(9,26 \pm 1,18)$ бала, $(9,67 \pm 0,62)$ бала і $(8,50 \pm 1,60)$ бала $(p<0,05) ;$ соціально-емоційної підтримки - $(8,78 \pm 1,24)$ бала, $(9,20 \pm 1,08)$ бала i $(8,00 \pm 1,20)$ бала $(p<0,05)$; громадської та службової підтримки - $(8,78 \pm 1,13)$ бала, $(9,13 \pm 1,06)$ бала і $(8,13 \pm 0,99)$ бала $(p<0,05)$; особистісної реалізації - $(9,17 \pm 1,07)$ бала, $(9,53 \pm 0,83)$ бала i $(8,50 \pm 1,20)$ бала $(p<0,05)$; духовної реалізації $(9,13 \pm 1,01)$ бала, $(9,47 \pm 0,83)$ бала i $(8,50 \pm 1,07)$ бала $(p<0,05) ; \quad$ загального сприйняття життя $(9,00 \pm 1,21)$ бала, $(9,33 \pm 1,05)$ балаі $(8,38 \pm 1,30)$ бала $(p<0,05)$. Інтегральні показники самооцінки ЯЖ у хворих із маніакальним варіантом ПЕ БАР такожє високими. Так, показник за сорерою суб'єктивного благополуччя/задоволеності склав, відпо-

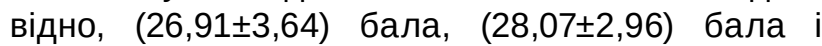
$(24,75 \pm 3,99)$ бала $(p<0,05) ;$ за сорерою виконання соціальних ролей - $(36,78 \pm 3,91)$ бала, $(38,20 \pm 3,10)$ бала і $(34,13 \pm 4,05)$ бала ( $<0,05) ;$ за сорерою зовнішніх життєвих умов - $(26,70 \pm 3,10)$ бала, $(27,80 \pm 2,91)$ бала i $(24,63 \pm 2,39)$ бала $(p<0,05)$. Сумарний показник ЯЖ у цій групі хворих склав $(90,39 \pm 10,35)$ бала, $(94,07 \pm 8,79)$ бала і $(83,50 \pm 9,96)$ бала $(p<0,05)$.

Структура самооцінки ЯЖ у хворих із маніакальним варіантом ПЕ БАР суттєво відрізняється від тієї, яка була виявлена у хворих із депресивним варіантом (рис. 2). При маніакальному варіанті ПЕ БАР домінуючою є сорера виконання соціальних ролей (40,7 \% у всіх хворих, 40,6 \% в чоловіків, 40,9 \% у жінок), а сфрери суб'єктивного благополуччя/задоволеності та зовнішніх життєвих умов мають приблизно рівну питому вагу (відповідно 29,8 \%, 29,8 \% і 29,6 \% та 29,5\%, 29,6 \% і 29,5 \%). Відмінностей за структурою самооцінки ЯЖ між чоловіками та жінками не виявлено (розбіжності статистично не значущі, р>0,05).

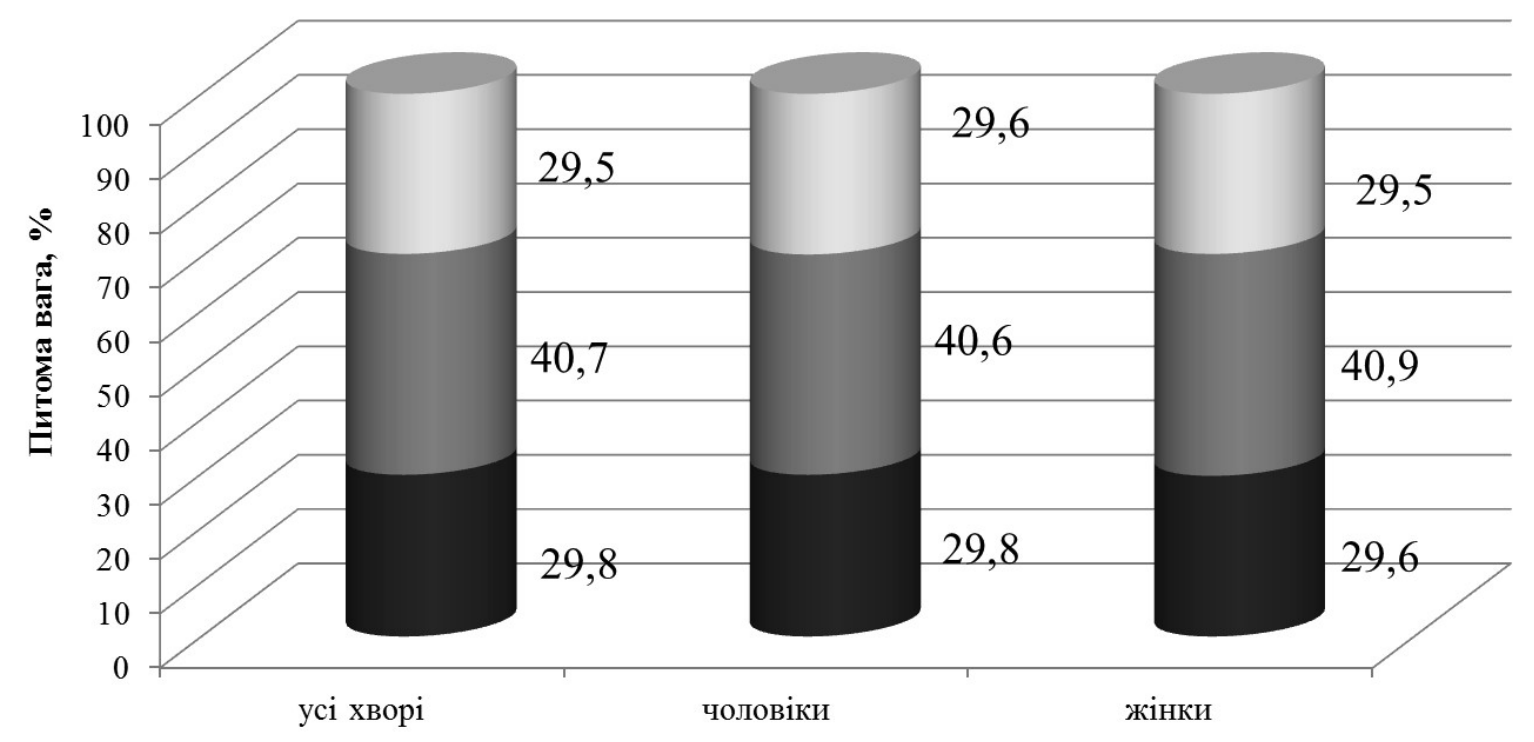

\# Зовнішні життєві умови $\quad$ Виконання соціальних ролей $\quad$ Суб'єктивне благополуччя/задоволеність

\section{Puc. 2. Структура самооцінки якості життя у різних сферах за шкалою Mezzich в адаптації Н. О. Марути у хворих із маніакальним варіантом ПЕ БАР.}

Для змішаного варіанта ПЕ БАР характерні складні закономірності оцінки ЯЖ, зумовлені клінічною гетерогенністю цієї групи, із загальною тенденцією до більш високих показників ЯЖ у чоловіків за деякими сферами: фрізичного благополуччя (відповідно $(4,18 \pm 2,27)$ бала, $(5,50 \pm 2,07)$ бала і $(2,60 \pm 1,34)$ бала, $p<0,05)$; психологічного (емоційного) благополуччя $((3,27 \pm 2,15)$ бала, $(4,50 \pm 2,07)$ бала i $(1,80 \pm 1,10)$ бала, $p<0,05)$; самообслуговування і незалежності дій $((5,82 \pm 1,89)$ бала,
$(6,83 \pm 1,72)$ бала і $(4,60 \pm 1,34)$ бала, $p>0,05)$; працездатності $((2,91 \pm 2,21)$ бала, $(3,83 \pm 2,56)$ бала і $(1,80 \pm 1,10)$ бала, p>0,05); міжособистісної взаємодії $((2,55 \pm 1,37)$ бала, $(2,83 \pm 1,47)$ бала і $(2,20 \pm 1,30)$ бала, $p>0,05)$; соціально-емоційної підтримки $((5,18 \pm 2,27)$ бала, $(6,50 \pm 2,07)$ бала i $(3,60 \pm 1,34)$ бала, $p<0,05)$; громадської та службової підтримки $((5,82 \pm 1,89)$ бала, $(6,83 \pm 1,72)$ бала і $(4,60 \pm 1,34)$ бала, p>0,05); особистісної реалізації $((5,09 \pm 2,12)$ бала, $(6,33 \pm 1,86)$ бала 
і $(3,60 \pm 1,34)$ бала, p<0,05); духовної реалізації $((3,45 \pm 2,34)$ бала, $(4,67 \pm 2,34)$ бала i $(2,00 \pm 1,41)$ бала, p>0,05); загального сприйняття життя $((4,45 \pm 2,46)$ бала, $(5,83 \pm 2,48)$ бала i $(2,80 \pm 1,10)$ бала, $\mathrm{p<0,05).}$

Інтегральні показники ЯЖ у цій групі також $€$ помірними: за сорерою суб'єктивного благополуччя/задоволеності, відповідно, $(6,91 \pm 4,30)$ бала, $(08,50 \pm 4,76)$ бала і $(5,00 \pm 3,08)$ бала $(p>0,05)$; виконання соціальних ролей - $(13,09 \pm 6,55)$ бала, $(15,67 \pm 7,37)$ бала і $(10,00 \pm 4,18)$ бала (p>0,05); зовнішніхжиттєвихумов- $(13,91 \pm 4,46)$ бала, $(16,00 \pm$ $3,85)$ бала і $(11,40 \pm 4,10)$ бала (p>0,05). Сумарний показник ЯЖ у хворих зі змішаним варіантом

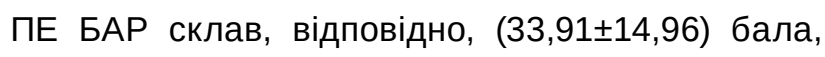
$(40,17 \pm 15,78)$ бала і $(26,40 \pm 10,92)$ бала $(p>0,05)$.

Структура самооцінки ЯЖ у хворих зі змішаним варіантом ПЕ БАР відрізняється від виявленої у хворих із депресивним і маніакальним варіантом (рис. 3). Сорери зовнішніх життєвих умов і виконання соціальних ролей є близькими за питомою вагою (всього 41,0 \%, у чоловіків 39,8 \% і у жінок 43,2 \% та 38,6 \%, 39,0 \% і 37,9 \% відповідно), суттєво меншою є питома вага сфери суб'єктивного благополуччя/задоволеності (відповідно 20,4 \%, 21,2 \% і 18,9 \%). Розбіжності у структурі самооцінки ЯЖ у чоловіків та жінок є статистично не значущими ( $p>0,05)$.

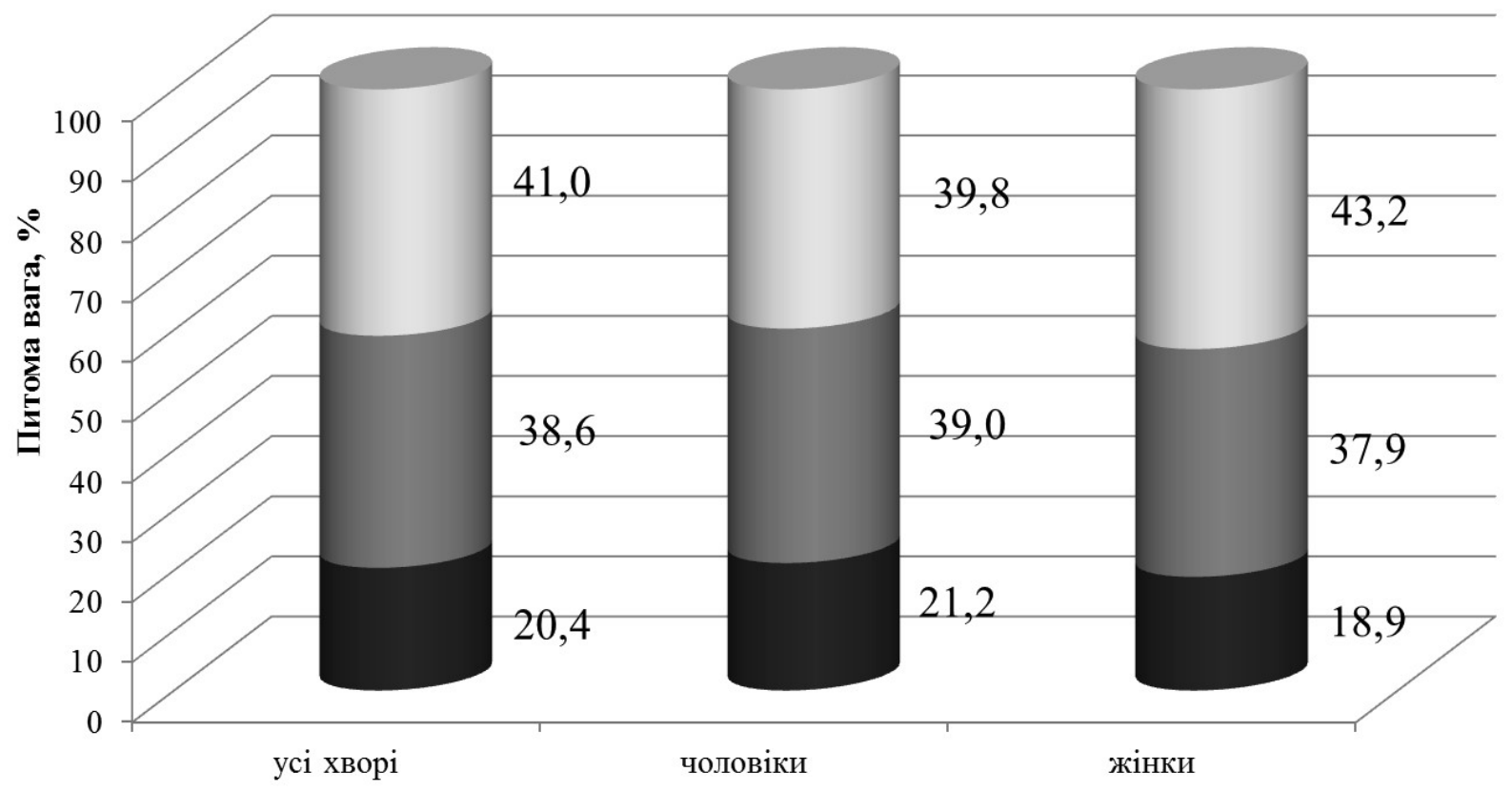

— Зовнішні життєві умови Виконання соціальних ролей $\quad$ Суб'єктивне благополуччя/задоволеність

Рuc. 3. Структура самооцінки якості життя у різних сферах за шкалою Mezzich в адаптації н. О. Марути у хворих зі змішаним варіантом ПЕ БАР.

На наш погляд, низькі показники самооцінки ЯЖ у хворих із депресивним варіантом ПЕ БАР $€$ наслідком впливу депресивного стану. Досліджений контингент складався переважно з молодих, орізично здорових людей, у яких були відсутні серйозні соматичні захворювання і проблеми; однак були виражені симптоми депресії. Найнижчими у цих хворих виявилися показники за сорерою психологічного (емоційного) благополуччя, що також визначалося депресивним станом із притаманною йому фіксацією на тяжких психічних переживаннях і схильністю песимістично оцінювати власний психоемоційний стан. Серед інтегральних сорер найнижчими у хворих із депресивним варіантом ПЕ БАР виявилися показники суб'єктивного благополуччя/задоволеності, що пов'язано з притаманною депресивному стану ангедонією, яка проявляється у втраті задоволення від життя, від видів діяльності, які раніше таке задоволення приносили. Невисокі значення за цією сорерою зумовлені загальною тенденцією хворих при депресивному стані сприймати об'єктивну реальність у песимістичному світлі, схильністю розглядати відносини 3 оточуючими крізь призму депресивних переживань, наявністю ідей самоприниження, що призводить до заниження суб'єктивної оцінки у більшості сорер ЯЖ.

Високі показники ЯЖ за всіма сорерами у хворих 3 маніакальним варіантом ПЕ БАР, на наш погляд, також зумовлені насамперед їх психічним станом. Маніакальний і гіпоманіакальний стан, що супроводжується піднесеним настроєм, відчуттям припливу сил, надзвичайної активності, бадьорості, патологічним оптимізмом і под., накладає суттєвий відбиток на сприйняття хворим об'єктивної реальності. 
У хворих зі змішаним варіантом ПЕ БАР самооцінка ЯЖ відрізняється як від тієї, що була виявлена у хворих $з$ депресивним варіантом, так і від виявленої у хворих із маніакальним варіантом ПЕ БАР. У цілому показники за окремими сорерами ЯЖ у хворих зі змішаним варіантом ПЕ БАР займають проміжне положення між показниками, характерними для депресивного і маніакального варіантів; при цьому показники, що характеризують ЯЖ у ключових сорерах, більш близькі до депресивного, а не до маніакального варіанта, причому в чоловіків показники суттєво вищі $(p<0,05)$, ніж у жінок. На наш погляд, такі особливості зумовлені відмінністю у клінічних проявах змішаного варіанта ПЕ БАР із переважанням у чоловіків гіпоманіакальних (включаючи атипові манії) і нестійких форм афективних розладів, а у жінок субдепресивних, апатичних і астенічних фрорм.

Порівняння показників ЯЖ у хворих із різними варіантами ПЕ БАР виявило наявність значущих розбіжностей при порівнянні груп 3 маніакальним та депресивним варіантами за сорерами фрізичного благополуччя, психологічного (емоційного) благополуччя, самообслуговування та незалежності дій, міжособистісної взаємодії, духовної реалізації, загального сприйняття життя, суб'єктивного благополуччя/задоволеності, виконання соціальних ролей та зовнішніх життєвих умов - для всіх хворих $(p<0,01)$, чоловіків $(p<0,01)$ і жінок ( $<<0,05)$, психологічного (емоційного) благополуччя, соціально-емоційної підтримки - для всіх хворих $(p<0,01)$ та жінок $(p<0,01)$, громадської та службової підтримки - для всіх хворих $(p<0,01)$ та жінок $(p<0,05)$, особистісної реалізації - для всіх хворих $(p<0,05)$ та жінок $(p<0,01)$. Інтегральний показник ЯЖ при порівнянні груп з депресивним і маніакальним варіантами ПЕ БАР значуще відрізняється у всіх хворих $(p<0,05)$ та в чоловіків $(p<0,01)$.

При порівнянні показників ЯЖ у хворих з депресивним і змішаним варіантами ПЕ БАР статистично значущі розбіжності були виявлені за сорерами міжособистісної взаємодії, соціально-емоційної підтримки, громадської та службової підтримки, духовної реалізації та зовнішніх життєвих умов для всіх хворих $(p<0,01)$, для чоловіків $(p<0,01)$ та жінок $(p<0,01)$, фрізичного благополуччя - для всіх хворих $(p<0,01)$ і для жінок $(p<0,01)$, психологічного (емоційного) благополуччя - для жінок $(p<0,01)$, за сорерами самообслуговування i незалежності дій та працездатності - для жінок $(p<0,05)$, особистісної реалізації - для чоловіків $(p<0,01)$, загального сприйняття життя - для жінок $(p<0,01)$, суб'єктивного благополуччя/задоволеності - для всіх хворих $(p<0,05)$ і для жінок
( $<<0,01)$, виконання соціальних ролей, а також за інтегральним показником ЯЖ - для всіх хворих $(p<0,01)$ та для жінок $(p<0,01)$.

Порівняння показників ЯЖ у хворих 3 маніакальним і змішаним варіантами ПЕ БАР виявило значущі розбіжності за сорерами фрізичного благополуччя, громадської та службової підтримки - для всіх хворих (p<0,01), для чоловіків $(p<0,01)$ і для жінок $(p<0,01)$, за сорерами психологічного (емоційного) благополуччя, соціальноемоційної підтримки, загального сприйняття життя, суб'єктивного благополуччя/задоволеності, зовнішніх життєвих умов, а також інтегрального показника ЯЖ - для всіх хворих $(p<0,01)$ та для жінок ( $<<0,01)$; за сорерою самообслуговування i незалежності дій - для всіх хворих $(p<0,01)$ і для чоловіків $(p<0,01)$, працездатності - для жінок $(p<0,01)$, міжособистісної взаємодії - для всіх хворих $(p<0,01)$, для чоловіків $(p<0,05)$ і для жінок $(p<0,05)$, особистісної реалізації - для чоловіків $(p<0,01)$ і для жінок $(p<0,05)$, духовної реалізації - для всіх хворих $(p<0,05)$ і для жінок $(p<0,05)$ та за сорерою виконання соціальних ролей - для жінок $(p<0,05)$.

\section{Висновки}

1. Хворим із первинним епізодом біполярного афективного розладу притаманні специфічні характеристики самооцінки якості життя, зумовлені переважно клінічним варіантом первинного епізоду.

2. При депресивному варіанті первинного епізоду БАР самооцінки ЯЖ є низькими, що зумовлено притаманним депресивному стану зниженим настроєм, песимізмом, схильністю розглядати усі події крізь призму депресивних переживань, фріксацією на хворобливих переживаннях, ідеями самоприниження.

3. При маніакальному варіанті первинного епізоду БАР самооцінки ЯЖ є високими, що пов'язано з притаманним маніакальному стану патологічно підвищеним настроєм, гіперактивністю, відчуттям припливу енергії, невиправданим оптимізмом, психоемоційним збудженням.

4. Змішаний варіант первинного епізоду БАР характеризується помірними показниками ЯЖ, що пов'язано з поліморфністю клінічних проявів та нестійкістю психоемоційного стану.

5. У жінок показники якості життя за основними сорерами нижчі, ніж у чоловіків, що пов'язано 3 більшою вираженістю у них депресивних проявів.

Перспективи подальших наукових досліджень полягають у розробці на основі отриманих даних сучасних підходів до профрілактики, лікування та реабілітації хворих на БАР. 
Список літератури

1. Критерий качества жизни в психиатрической практике / Н. А. Марута, Т. В. Панько, И. А. Явдак [и др.] ; под общ. ред. Н. А. Маруты. - Харьков : РИФ Арсис, ЛТД, 2004. - 240 с.

2. A report on older-age bipolar disorder from the International Society for Bipolar Disorders Task Force / M. Sajatovic,

S. A. Strejilevich, A. G. Gildengers [et al.] // Bipolar Disorders. - 2015. - Vol. 17 (7). - P. 689-704.

3. Clinical Practice Guidelines for Bipolar Affective Disorder (BPAD) in children and adolescents / S. Gautam, A. Jain,

M. Gautam [et al.] // Indian Journal of Psychiatry. - 2019. - Vol. 61 (2). - P. 294-305.

4. Improving functioning, quality of Life, and well-being in patients with bipolar disorder / C. Del Mar Bonnin, M. Reinares,

A. Martinez-Azan [et al.] // International Journal of Neuropsychopharmacology. - 2019. - Vol. 22 (8). - P. 467-477.

5. Maripuuab M. Quality of life for patients diagnosed with bipolar disorder: Lifestyle and treatment / M. Maripuuab,

K. F. Norrbackab, R. Adolfssonab // Neurology, Psychiatry and Brain Research. - 2019. - Vol. 34. - P. 34-40.

6. Nabavi B. A Lifetime prevalence of comorbidity between bipolar affective disorder and anxiety disorders: A meta-analysis of 52 interview-based studies of psychiatric population / B. Nabavi, A. J. Mitchell, D. Nuttc // E. Bio. Medicine. - 2015. Vol. 2 (10). - P. 1405-1419.

7. Pond E. Mood instability linked to stress, decreased quality of life in bipolar disorder / E. Pond // Psychiatry Advisor. 2019. - Vol. 7. - P. 2-4.

8. Quality of life in euthymic patients with unipolar major depressive disorder and bipolar disorder / Q. Bo, L. Tian, F. Li [et al.] // Neuropsychiatric Disease and Treatment. - 2019. - Vol. 15. - P. 1649-1657.

9. Shumye $S$. Health related quality of life and its correlates among people with depression attending outpatient department in Ethiopia: a cross sectional study / S. Shumye, Z. Belayneh, N. Mengistu // Health and Quality of Life Outcomes. 2019. - Vol. 17 (169). - P. 1233-1237.

10. Subjective neurocognition and quality of life in patients with bipolar disorder and siblings / A. Tatay-Manteigaa, O. Caulib, R. Tabarés-Seisdedosc [et al.] // Journal of Affective Disorders. - 2019. - Vol. 245. - P. 283-288.

\section{References}

1. Maruta, N.A., Panko, T.V., Yavdak, I.A., \& Semykina, E.E. (2004). Kriteriy kachestva zhizni v psikhiatricheskoy praktike [Quality of life criterion in psychiatric practice]. Kharkiv: RIF Arsis, Ltd [in Russian].

2. Sajatovic M., Strejilevich S.A., Gildengers A.G., Dols A., Al Jurdi R.K. Brent P Forester ... \& Kenneth I. Shulman. (2015). A report on older-age bipolar disorder from the International Society for Bipolar Disorders Task Force. Bipolar Disorders, 17 (7), 689-704.

3. Gautam, S., Jain, A., Gautam, M., Gautam, A., \& Jagawat, T. (2019). Clinical Practice Guidelines for Bipolar Affective Disorder (BPAD) in children and adolescents. Indian Journal of Psychiatry, 61 (2), 294-305.

4. Del Mar Bonnin, C., Reinares, M., Martinez-Azan, A., Jimenez, E., Sanchez-Moreno, J., Sole, B., Montejo, L., \& Vieta, E. (2019). Improving functioning, quality of life, and well-being in patients with bipolar disorder. International Journal of Neuropsychopharmacology, 22 (8), 467-477.

5. Maripuuab, M., Norrbackab, K.F., \& Adolfssonab, R. (2019). Quality of life for patients diagnosed with bipolar disorder: Lifestyle and treatment. Neurology, Psychiatry and Brain Research, 34, 34-40.

6. Nabavi, B., Mitchell, A.J., \& Nuttc, D. (2015). A lifetime prevalence of comorbidity between bipolar affective disorder and anxiety disorders: A meta-analysis of 52 interview-based studies of psychiatric population. EBioMedicine, 2(10), 14051419.

7. Pond, E. (2019). Mood instability linked to stress, decreased quality of life in bipolar disorder. Psychiatry Advisor, 7, 2-4. 8. Bo, Q., Tian, L., Li, F., Mao, Z., Wang, Z., Ma, X., \& Wang, C. (2019). Quality of life in euthymic patients with unipolar major depressive disorder and bipolar disorder. Neuropsychiatric Disease and Treatment, 15, 1649-1657.

9. Shumye, S., Belayneh, Z., \& Mengistu, N. (2019). Health related quality of life and its correlates among people with depression attending outpatient department in Ethiopia: a cross sectional study. Health and Quality of Life Outcomes, 17 (169), 1233-1237.

10. Tatay-Manteigaa, A., Caulib, O., Tabarés-Seisdedosc, R., Michalakd, E.E., Kapczinskief, F., \& Balanzá-Martínezc, V. (2019). Subjective neurocognition and quality of life in patients with bipolar disorder and siblings. Journal of Affective Disorders, 245, 283-288.

\section{SOME FEATURES OF QUALITY OF LIFE IN THE PRIMARY EPISODE OF BIPOLAR AFFECTIVE DISORDER}

Yu. I. Mysula

I. Horbachevsky Ternopil National Medical University, Ternopil, Ukraine

Purpose: to investigate the quality of life in patients with primary episode of $B A D$, taking into account the sex and clinical version of the diseases debut.

Materials and Methods. We have clinically examined 65 men and 88 women diagnosed with bipolar affective disorder in the period 2011-2016 using the Mezzich Quality of Life Scale.

Results. Low rates of quality of life were found in the depressive variant of the primary episode of BAD in all areas: subjective well-being/satisfaction (7.04 \pm 2.52$)$ points in all patients, $(7.86 \pm 2.80)$ points in men, and $(6.56 \pm 2.21)$ points in women $(p<0.05)$, social roles $(13.68 \pm 4.89)$ points, $(15.18 \pm 4.29)$ points and $(12.80 \pm 5.03)$ points $(p<0.05)$, external living conditions $(16.11 \pm 5.73)$ points, $(17.34 \pm 5.47)$ points and $(15.39 \pm 5.78)$ points $(p>0.05)$, as well as the total quality of life score $-(36.83 \pm 12.52)$ points, $(40.39 \pm 12.03)$ points and $(34.75 \pm 12.41)$ points $(p<0.05)$. In 
patients with a manic variant, indicators in all spheres are high: respectively (26.91 \pm 3.64$)$ points, $(28.07 \pm 2.96)$ points and $(24.75 \pm 3.99)$ points $(p<0.05)$; $(36.78 \pm 3.91)$ points, $(38.20 \pm 3.10)$ points and $(34.13 \pm 4.05)$ points $(p<0.05)$; $(26.70 \pm 3.10)$ points, $(27.80 \pm 2.91)$ points and $(24.63 \pm 2.39)$ points $(p<0.05)$ and $(90.39 \pm 10.35)$ points, $(94.07 \pm 8.79)$ points and $(83.50 \pm 9.96)$ points $(p<0.05)$, and in the mixed variant - moderate: respectively $(6.91 \pm 4.30)$ points, $(8.50 \pm 4.76)$ points and $(5.00 \pm 3.08)$ points $(p>0.05)$; $(13.09 \pm 6.55)$ points, $(15.67 \pm 7.37)$ points and $(10.00 \pm 4.18)$ points $(p>0.05)$; $(13.91 \pm 4.46)$ points, $(16.00 \pm 3.85)$ points and $(11.40 \pm 4.10)$ points $(p>0.05)$ and (33.91 \pm 14.96$)$ points, $(40.17 \pm 15.78)$ scores and $(26.40 \pm 10.92)$ points $(p>0.05)$.

Conclusions. In the depressive variant of the primary episode of BAD revealed low, and in the manic - high self-esteem quality of life in all areas, which is due to the influence of the current state of the affective sphere. In the mixed variant of the primary episode, moderate quality of life indices were found, which is related to the polymorphism of clinical manifestations and instability of the psycho-emotional state. In women, quality of life in the main areas is lower than in men, which is associated with a greater severity of depressive symptoms.

KEY WORDS: bipolar affective disorder; the primary episode; quality of life.

Рукопис надійшов до редакції 23.12.2019 р.

\section{Відомості про автора:}

Мисула Юрій Ігорович - кандидат медичних наук, доцент кафедри психіатрії, наркології та медичної психології Тернопільського національного медичного університету імені І. Я. Горбачевського МОЗ України; тел.: +38(0352) 43-57-71. 